\title{
STUDY OF RISK FACTORS FOR CONEGNITAL HEART DEFECT IN A TERTIARY LEVEL HOSPITAL
}

\author{
FH POLY ${ }^{1}, \mathrm{~S} \mathrm{AFROZA}^{2}, \mathrm{H}^{\mathrm{RAHMAN}}{ }^{3}, \mathrm{MI} \mathrm{HASSAN}^{4}$
}

\begin{abstract}
:
A congenital heart defect is a heart problem which is present at birth, caused by improper development of the heart during fetal development. In majority of cases there is no known reason for the heart to develop improperly. Some type of congenital heart defects are related to chromosomal abnormality(5-6\%), some are to single gene defect(3-5\%) or environmental factors(2\%). In 85-90\% of cases there is no identifiable cause and are generally considered to be caused by multifactorial inheritance. There are some maternal factors which have some role in cardiovascular malformations. These include high maternal age(above 30 years), maternal obesity, consanguinity among the parents, fever during pregnancy, gestational diabetes mellitus, smoking, alcohol consumption, ingestion of any teratogenic drug including homeopathy and herbal medicine.
\end{abstract}

Objective of the study: To evaluate the risk factors associated with congenital heart disease.

Methodology: A case control study was conducted at paediatric department of Sir Salimullah Medical College \& Mitford Hospital following approval of the protocol from $1^{\text {st }}$ January 2013 to $30^{\text {th }}$ June 2014. Children fulfilling the inclusion criteria- $(0-5$ year old children of both sexes admitted in paediatric units of Mitford Hospital with any type of congenital heart disease confirmed by echocardiography) were considered as cases. A similar number of age and sex matched children admitted in Mitford Hospital without any cardiac defect were considered as controls. Data were collected by questionnaire.

Results: The results show that majority of the cases are male. Maternal age (27.09 \pm 4.63$)$ and $B M I(24.10 \pm 2.28)$ both are significantly higher in cases than those of controls. Among the cases 31.8\% mothers had consanguineous marriage $(p=0.001)$ and $27.1 \%$ mothers had history of fever during pregnancy whereas it was present in $9.3 \%$ mothers of controls, the difference is significant statistically ( $p=0.001)$. Among the cases $34.6 \%$ mothers had history of gestational diabetes mellitus and only $18.9 \%$ controls had so and the difference is significant statistically $(p=0.014)$.

Conclusion: Relatively old age and more weight during pregnancy, consanguinity between parents, fever during pregnancy, history of gestational diabetes mellitus are the main risk factors of congenital heart defects in children.

J Dhaka Med Coll. 2018; 27(1) : 51-56

\section{Introduction}

Congenital heart disease is the commonest of all congenital lesions and is the most common type heart disease in the children. ${ }^{1}$ In a definition proposed by Mitchell et al, congenital heart disease is a" gross structural abnormality of heart and intrathoracic great vessels that is actually or of functional significance". ${ }^{2}$ Congenital heart disease occurs in approximately $0.8 \%$ of live births. ${ }^{3}$ The incidence is higher in stillborns(3\%-4\%), spontaneous abortuses $(10 \%-25 \%) \&$ premature infants $(2 \%)$ excluding patent ductus arteriosus. ${ }^{4}$ Congenital heart disease remains the leading cause of death in children among congenital malformations. ${ }^{5}$

The cause of most congenital heart defects is unknown. 1, 4-6 Most cases of CHD were thought to be multifactorial and result from a combination of genetic predisposition and

1. Dr. Ferdousi Hossain Poly, Assistant Registrar, Department of Paediatrics, Sir Salimullah Medical College \& Mitford Hospital.

2. Professor Dr. Syeda Afroza, Professsor \& Head, Department of Paediatrics, Sir Salimullah Medical College \& Mitford Hospital.

3. Dr. Hasanur Rahman, Assistant Professor, Department of Pharmacology, Dhaka Medical College.

4. Dr. Md. Imran Hassan, Resident,Phase B, Department of Pathology, Bangabandhu Sheikh Mujib Medical University. Correspondence: Dr. Ferdousi Hossain Poly, Medical Officer, Personal Division, Presidents Office, Bongobhabon, Dhaka.email: dr.polyk55@gmail.com,mobile-01718119811

Received: 21 July 2017

Revision: 01 September 2017

Accepted: 15 September 2017

DOI: http://dx.doi.org/10.3329/jdmc.v27i1.38946 
environmental stimulus. ${ }^{1}$, 4-6 Multifactorial inheritance means that "many factors" are involved in causing a birth defect. The factors are usually both genetic and environmental, where a combination of genes from both parents in addition to unknown environmental factors produce the trait or condition. A small percentage of congenital heart lesions are related to Chromosomal abnormalities, in particular, trisomy 21,13 \& 18 \& Turner syndrome. ${ }^{5}$ Other genetic factor may have a role in CHD; certain types of VSDs (supracristal) are more common in Asian children. ${ }^{5}$ The risk of recurrence of CHD increases if a $1^{\text {st }}$ degree relative(parent or sibling) is affected. $4,5,7$ Scientists know that some types of congenital heart defects can be related to an abnormality of an infant's chromosomes( $5 \%-6 \%)$, single gene $\operatorname{defect}(3 \%-5 \%)$ or environmental factors $(2 \%){ }^{5}$ In $85 \%-90 \%$ of cases there is no identifiable cause for the heart defect and they are generally considered to be caused by multifactorial inheritance. ${ }^{1,4,5}$

However some types of CHD are known to occur more often when the mother comes in contact with certain substances during the first few weeks pregnancy. ${ }^{4,7}$ Some maternal illness and medications taken for these illnesses have been shown to affect the heart's development. ${ }^{4,7}$ Women who have seizure disorders and need to take anti-seizure medications may have a higher risk for having a child with CHD, as do women who take lithium to treat depression. ${ }^{4}$ Mothers who have phenylketonuria (PKU) who do not adhere to the special diet necessary to manage the disease during pregnancy have higher risk of having a child with CHD. ${ }^{4}$ Also women with insulin dependant diabetes mellitus (particularly if the diabetes is not well controlled) or lupus may have a higher risk of having a child with CHD . 4,7,9 The risk increases when either parent has CHD or when another sibling was born with CHD. 4,7

Parental consanguinity is a risk factor for CHD worldwide suggesting that a recessive inheritance model may contribute substantially to CHD. ${ }^{10}$

A mother who contacts rubella virus during her pregnancy has a very high risk of having a child with CHD. 4,5,7-9,11 Some heart defects are considered to have autosomal dominant $i$ The risk increases when either parent has CHD or when another sibling was born with CHD. 4,7

\section{Methodology \\ Materials and Methods \\ Study design \\ Case-control study}

\section{Place of study}

Department of Paediatrics, Sir Salimullah Medical college \& Mitford Hospital, Dhaka.

\section{Period of study}

From 1st January 2013 to $30^{\text {th }}$ June 2014

\section{Inclusion criteria}

- Children admitted in paediatric units of Sir Salimullah Medical College \& Mitford Hospital with any type of congenital heart disease confirmed by echocardiography.

- Age: 0 -5 year

- Sex: Both male and female

- 107 age and sex matched controls were taken from paediatrics indoor of Sir Salimullah Medical College \& Mitford Hospital, Dhaka, having illness other than congenital heart disease.

\section{Exclusion criteria}

Children having severe illness like chronic kidney disease (CKD), chronic liver disease (CLD), Hepatic encephalopathy or any other moribund condition.

\section{Study procedure}

Children, both male and female aged 0-5 years with suspected congenital heart disease were enrolled in the study. After taking detailed history they were examined thoroughly and provisional diagnosis was made. The provisional diagnosis was then confirmed by chest $X$ ray and echocardiography. After confirmation of diagnosis data were collected using a structured questionnaire. The cases which were not confirmed by echocardiography were excluded from the study. Children who had no congenital heart disease confirmed by history, clinical examination and chest $\mathrm{x}$-ray but were admitted in paediatrics units of the same hospital for their 
other illness were considered as controls and data were collected by using the same questionnaire.

\section{Data Analysis}

After collection of all data it was statistically analysed using the software named Statistical
Package for the Social Sciences(IBM SPSS ) version 17.In analysis for comparison of quantitative data Student $t$ test and for qualitative data chi-square test was used.In both cases confidence interval upto $95 \%$ and $p$ value $<0.05$ are considered as significant. The results were then displayed in tabulated form.

\section{Results}

Table - I

Age distribution of studied children

\begin{tabular}{cccccc}
\hline Characteristics & $\begin{array}{c}\text { Case } \\
\text { Mean } \pm \text { SD }\end{array}$ & $\begin{array}{c}\text { Control } \\
\text { Mean } \pm \text { SD }\end{array}$ & t-test & df & $\begin{array}{c}p \\
\text { Age in months }\end{array}$ \\
\hline $15.60 \pm 4.8$ & $15.78 \pm 5.4$ & 0.086 & 212 & 0.932 \\
\hline
\end{tabular}

Table I shows the age distribution of cases and controls where both the groups were of similar age.

\section{Table - II}

Sex distribution of studied children

\begin{tabular}{lccccc}
\hline Sex & Case & Control & Chi-square & df & $\mathrm{p}$ \\
\hline Male & $\mathrm{N}(\%)$ & $\mathrm{N}(\%)$ & & & \\
Female & $63(58.9)$ & $60(56.1)$ & & 0.678 \\
Total & $44(41.1)$ & $47(43.9)$ & 0.172 & 1 & \\
\hline
\end{tabular}

Table II shows the sex distribution of studied children where male: female in case group was 1.4: 1 and in control it was $1.2: 1$. The ratio did not differ significantly among the cases and controls(Table II).

Table- III

Types of Congenital heart 3: disease among the studied children

\begin{tabular}{lcc}
\hline Name of heart defect & Total number of patients & Percentage of patients \\
\hline VSD & 42 & 39.2 \\
ASD & 30 & 28.0 \\
TOF & 16 & 14.9 \\
PDA & 09 & 8.4 \\
AV Canal defect & 02 & 1.86 \\
TGA & 02 & 1.86 \\
CoA & 02 & 1.86 \\
Others & 05 & 4.67 \\
\hline
\end{tabular}

Among the cases most children(39.2\%) are of VSD.Then ASD (28\%) and TOF $(14.9 \%)$ are the commonest (Table III). 
Table-IV

Average maternal age and BMI of studied children

\begin{tabular}{lccccc}
\hline Characteristics & $\begin{array}{c}\text { Case } \\
\text { Mean } \pm \text { SD }\end{array}$ & $\begin{array}{c}\text { Control } \\
\text { Mean } \pm \text { SD }\end{array}$ & t-test & df & p \\
\hline Maternal age & $27.09 \pm 4.63$ & $24.06 \pm 3.79$ & 5.230 & 212 & 0.000 \\
Maternal BMI & $24.10 \pm 2.28$ & $22.94 \pm 3.69$ & 2.769 & 212 & 0.006 \\
\hline
\end{tabular}

The mean of maternal age was 27 years and 24 years among cases and controls respectively and their corresponding BMI was 24 and 22 and the difference was statistically significant, i.e. the age and BMI of mothers of cases were significantly higher than those of controls (Table 4) .

Table-V

Consanguinity among studied children

\begin{tabular}{lccccc}
\hline Consanguinity & Case & Control & Chi-square & df & p \\
& $\mathrm{N}(\%)$ & $\mathrm{N}(\%)$ & & & \\
\hline Present & $34(31.8)$ & $14(13.1)$ & & 1 & 0.001 \\
Absent & $73(68.2)$ & $93(86.9)$ & 10.743 & & \\
Total & $107(100.0)$ & $107(100.0)$ & & & \\
\hline
\end{tabular}

Table V shows that among cases consanguinity was present in $31.8 \%$ babies conversely among controls it was present in $13.1 \%$ babies. Statistically this difference was significant.(Table 5).

Table-VI

Distribution of mother of studied children having history of fever during pregnancy

\begin{tabular}{lccccc}
\hline $\begin{array}{l}\text { History of } \\
\text { fever }\end{array}$ & $\begin{array}{c}\text { Case } \\
\mathrm{N}(\%)\end{array}$ & $\begin{array}{c}\text { Control } \\
\mathrm{N}(\%)\end{array}$ & Chi-square & $\mathrm{df}$ & $\mathrm{p}$ \\
\hline Yes & $29(27.1)$ & $10(9.3)$ & & & \\
No & $78(72.9)$ & $97(90.7)$ & 11.319 & 1 & 0.001 \\
\hline Total & $107(100.0)$ & $107(100.0)$ & & & \\
\hline
\end{tabular}

Among the mothers of studied babies $27.1 \%$ cases had fever during pregnancy which was $9.3 \%$ among the controls and the difference was statistically significant(Table 6).

Table-VII

Distribution of studied children according to presence of having history of gestational diabetes mellitus in their mothers

\begin{tabular}{lccccc}
\hline $\begin{array}{l}\text { History of gestational } \\
\text { diabetes }\end{array}$ & $\begin{array}{c}\text { Case } \\
\mathrm{N}(\%)\end{array}$ & $\begin{array}{c}\text { Control } \\
\mathrm{N}(\%)\end{array}$ & Chi-square & $\mathrm{df}$ & $\mathrm{p}$ \\
\hline Yes & $37(34.6)$ & $17(18.9)$ & & & \\
No & $70(65.4)$ & $73(81.1)$ & & 1 & 0.014 \\
Total & $107(100)$ & $107(100.0)$ & 6.048 & & \\
\hline
\end{tabular}

More than one third of study subjects in case group had history of gestational diabetes mellitus(34.6\%), on the other hand only $18.9 \%$ controls had so and the difference is statistically significant (Table VII). 


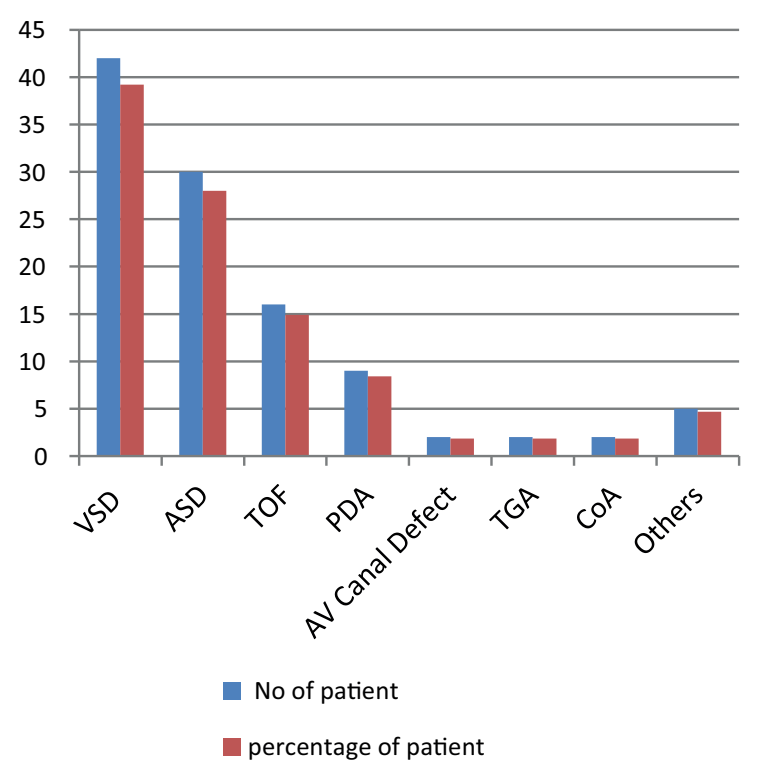

\section{Figure}

\section{Discussion}

In the present study number of male was a bit higher among the cases than controls $(58.9 \%$ and $56.1 \%$ respectively ) and among cases male female ratio was $1.43: 1$ which is consistent with the study done by Sharmin et al. ${ }^{2}$

In this study $57 \%$ cases had feeding problem, $56.1 \%$ cases had bronchopneumonia and $85 \%$ had murmur. Sharmin et $\mathrm{al}^{2}$ found $26.1 \%$ feeding problem which is similar to the present study. Study done by NN Fatema et $\mathrm{al}^{8}$ found $21.58 \%$ definite CHD had murmur and Sharmin et $\mathrm{al}^{2}$ found pansystolic murmur in $100 \%$ cases of VSD, ejection systolic murmur in $100 \%$ cases of TOF and $88.2 \%$ cases of ASD, continuous machinery murmur in $100 \%$ cases of PDA which is consistent with the present study.

In the present study mean maternal age among cases was $27.09 \pm 4.63$ and among controls age was $24.06 \pm 3.79$. NN Fatema et $\mathrm{al}^{3}$ also found $9.42 \%$ mother was beyond 30 years and Pijtsik et $\mathrm{al}^{12}$ found that the odds ratio(OR) was twice as high as the average value for pregnant women under 16 and three times as high for those over 41.

Mills et al $^{13}$ found all obese women having BMI $\geq 30$ were significantly more likely to have children with CHD than those with normal weight .They also found highly significant trend of increasing OR for CHD with increasing maternal obesity which is consistent with present study.

Huq FU et al ${ }^{14}$ found $48.8 \%$ babies having CHD were born of consanguineous marriages and Al-Ani ZR ${ }^{15}$ found $78 \%$ consanguinity among cases and $43.3 \%$ among controls which is almost similar to the present study. Fung et al ${ }^{16}$ found only $9 \%$ of CHD in first degree relatives.

Oster ME et $\mathrm{al}^{17}$ found significant association between fever and CHD especially right sided obstructive defect. They found OR 2.04\% with $95 \%$ confidence interval (CI) . Botto LD et al ${ }^{18}$ found that febrile illness during pregnancy was positively associated with the occurrence of heart defects in offspring (OR-1.8; 95\% CI=1.42.4) which is similar to the present study. In this study $27.1 \%$ cases had history of fever during pregnancy while only $9.3 \%$ controls had fever during pregnancy. NN Fatema et $\mathrm{al}^{8}$ found $2.13 \%$ mother had antenatal infection.

Corrigan et al. 2009 and Wren et al. 2003 found significant association with maternal gestational diabetes mellitus and congenital heart disease(OR 4.6 - 10) with 95\% confidence interval(CI). ${ }^{7}$ Another study done by Lisowsky et al. ${ }^{19}$ found significant association between gestational diabetes mellitus and congenital heart disease. In this study $34.6 \%$ mother of case group had history of gestational diabetes mellitus and the finding is similar to those studies.

\section{Conclusion}

From the result of the present study it can be concluded that elderly, obese mother, consanguineous parents, history of fever during pregnancy, history of gestational diabetes mellitus had a significant chance of having a child with congenital heart defect. To ascertain the significance of these findings, large and multi-centered case control studies are required to prove.

\section{Limitation of the study}

Sample size of this study was small. Multiple centers could not be involved. So, the result does not reflect the status of children of the whole country. 


\section{Recommendation}

Although congenital heart disease is a multifactorial disorder its risk can be reduced by some measures like

- Weight control during the periconceptional period

- Discourage about consanguinous marriage

- Ensure antenatal check up

- Maintenance of personal hygiene for prevention of fever and flu like illness during pregnancy.

\section{References}

1. Frederick JS. The heart. In: Cotran RS, Kumar VMD, Collins TMD, editors. Robins Pathologic Basis of Disease. $6^{\text {th }}$ ed. Philadelphia: Saunders. 1999. P. 592-3.

2. Sharmin LS, Haque MA, Bari MI, Ali MA. Pattern and clinical profile of congenital heart disease in a teaching hospital. The J of Teachers Association RMC, Rajshahi 2008; 21: 58-62

3. Fatema NN. Downs syndrome with congenital heart disease. Analysis of cases over 2 years in a tertiary hospital. CVJ 2010; 2: 184-7

4. Factors contributing to congenital heart disease. Available from http://www.lpch.org/ DiseaseHealthInfo/HealthLibrary/cardiac/ fcchd.html(Accessed on $4^{\text {th }}$ Feb 2013)

5. Bernstein D. Epidemiology and genetic basis of congenital heart disease. In: Kliegman RM, Behrman RE, Jenson HB, Stanton BF, editors. Nelson Text Book of Paediatrics. $18^{\text {th }}$ ed. Philadelphia Saunders: Elsevier; 2008. p. 1878-80.

6. Haslett C, Chilvers ER, Boon NA, Colledge NR. Congenital heart disease. In: Haslett $\mathrm{C}$, Chilvers ER, Boon NA, Colledge NR, editors. Davidsons principles and practice of medicine, $21^{\text {st }}$ ed. Churchill Livingstone; 2002. p. 467-475

7. Sayasathid J, Sukonpan K, Somboonna N. Epidemiology and Etiology of Congenital Heart Diseases. In: Congenital Heart Disease-Selected Aspects. Prof. Rao P S. editor. ISBN; 2012. p. 307472
8. Fatema NN, Chowdhury RB, Chowdhury L. Incidence of congenital heart disease among hospital live birth in a tertiary hospital of Bangladesh. CVJ 2008; 1 : $14-20$

9. Frier BM, Fisher BM. Diabetes Mellitus. In: Haslrtt C, Chilvers ER, Boon NA, Colledge N R, editors. Davidsons principles and practice of Medicine. $21^{\text {st }}$ ed. Churchill Livingstone; 2002. p. 679

10. Mollah MAH, Nahar N. Step on to Pediatrics. $2^{\text {nd }}$ ed. 2012.

11. Khan MR, Rahman ME. Essence of Pediatrics. $4^{\text {th }}$ ed. ELSEVIER; 2011.

12. Pejtsik B, Pinter J, Horvath M \& Hadnagy J. Relationship between congenital heart defect and various factors affecting pregnancy. The $\mathrm{J}$ of Paed $1992 ; 133: 155-158$

13. Mills JL, Troendle J, Conley MR, Caster T, Druschel CM. Maternal obesity and congenital heart defects: A population based study, Am J of Cli Nutri 2010 ; 91: 1543-9

14. Haq FU, Jalil F, Hashmi S, Jumani MI, Imdad A, Jabeen $\mathrm{M}$, et al. Risk factors predisposing to congenital heart defects, Ann Pediatr Cardiol 2011 ; 4: $117-121$.

15. Al-Ani ZR. Association of consanguinity with congenital heart disease in a teaching hospital in Western Iraq. Saudi Medical J 2010 ; 31 : 1021-7

16. Fung A, Manlhiot C, Naik S, Rosenberg H, Smythe J, Lougheed $\mathrm{J}$, et al. Impact of prenatal risk factors on congenital heart disease in the current era, J Am Heart Assoc 2013; 2: 1-12 Available from http:// jaha, ahajournals.org/content/2/3/e000064.full (accessed on 23 May 2014)

17. Oster ME, Riehle-Colarusso T, Alverson CJ \& Correa A. Association between maternal fever and influenza and congenital heart defects. The $\mathrm{J}$ of Paed 2011 ; 158 : 990-5

18. Botto LD, Lynberg MC, Erickson JD. Congenital heart defect, maternal febrile illness and multivitamin use: A population based study. Am J of Epi 2001; 12 : 485-90

19. Lisowski LA, Verheijen PM, Copel JA, Kleinman CS, Wassink S, Visser GH, et al. Congenital heart disease in pregnancies complicated by maternal diabetes mellitus, An international clinical collaboration, literature review and mete-analysis 2010 ; 35 : 1926 . 